No one wants to keep a sick person at work, but prevention of sickness by any means available is a good thing. A "breakdown" may conceivably bear some relation to being "fed-up."

\section{Nature of the Sickness.}

So far we have considered the amount of sickncss; in some cases it has been possible for us to compare the medical diagnoses. Such diagnoses would in all cases be made by a large number of different panel doctors in different neighbourhoods, so that no one doctor's fads of nomenclature can be represented. We have only considered the diagnoses for people on long sick leave-that is; over thirty dáys. These show extraordinary diversity, not only in the gross amount of illness, but in its nature, as indicated by its diagnostic classification. Here are the details of cases involving long sick leave during one year in two firms:

\begin{tabular}{|c|c|c|c|}
\hline \multicolumn{2}{|r|}{ Firm-F. C. } & \multicolumn{2}{|r|}{ Firm-H. W. } \\
\hline $\begin{array}{l}\text { Days } \\
\text { Lost. }\end{array}$ & Diagnosis. & $\begin{array}{l}\text { Days } \\
\text { Lost. }\end{array}$ & Diagnosis. \\
\hline A: 222 & Sarcoma of ilium. & A. 278 & Dysprpiaia and nervous \\
\hline B. 126 & Motor accident. & B. 243 & Pyrexia, hydronephrosis. \\
\hline C. 108 & Pulmonary tuberculo:is. & C. 181 & Cough. high blood pressure, \\
\hline D. 98 & Renal calculus; operation. & D. 159 & $\begin{array}{l}\text { bronchial catarrh. } \\
\text { Influenza, influenza de- } \\
\text { bilitity, nervous debility, } \\
\text { nervous exhaustion. }\end{array}$ \\
\hline E. 90 & Pulmonary tuberculosis. & E. 156 & Influenza and pleurisy. \\
\hline F. 72 & Appendicitis ; operation. & F. 140 & Rhinitis. \\
\hline G. 48 & Cold; abscess of thigh. & G. 124 & Nervous debility. \\
\hline H. 43 & Duodenal ulcer; operation. & H. 123 & Nervous breakdown. \\
\hline I. 42 & Influenza. & I. 109 & Cardiac and nervous over- \\
\hline J. 38 & Motor accident. & J. 105 & General debility. \\
\hline K. 33 & Appendicitis; operation. & K. 94 & Debility. \\
\hline L. 30 & Influenza. & L. 92 & $\begin{array}{l}\text { Debility after appendicitis, } \\
\text { influenza, and lumbago. }\end{array}$ \\
\hline \multicolumn{2}{|c|}{$\begin{array}{l}\text { Average days' sick leave her head } \\
\text { per annum for men and women } \\
=3.6 \text {. }\end{array}$} & \multicolumn{2}{|c|}{$\begin{array}{l}\text { Average dars' sick leave per head } \\
\text { per annum }=7.7 \text { for men and } 14 \text { for } \\
\text { women. }\end{array}$} \\
\hline
\end{tabular}

It is clear that there is considerable difference between the two firms, though both do the same kind of work, and both employ numbers of men and women. H. W. is remarkable for the number of diagnoses of the type called nervous breakdown, whereas that type is absent in F. C. With regard to these two firms we are able to throw some light on the difference.

In the course of an investigation into telegraphists' cramp $^{2}$ we had occasion to inquire into the type of person who got cramp, and were able to show that a majority of cramp subjects were of a psychoneurotic or "nervy" temperament-that is to say, that fear in some form played an undue part in their mental make-up. Continuing the problem of the incidence of the psychoneurotic temperament in the ordinary population, we have investigated sample groups of workers in several firms, among which are F. C. and H. W. F. C. is remarkable in having a higher percentage of people free from psyehoneurotic symptoms, and those with such svmptoms had them to a lesser degree than any other group. This is correlated with the absence of psychoneurotic illness. Circumstances peculiar to the firm directed the attention of the medical staff to the importance of excluding the temperamentally as well as the physically unfit, and their success in that direction is verified by the results. A study of the medical diagnoses of $\mathrm{H}$. W. showed that at least 51 per cent. of the long sick leave was psychoneurotic in character. F. C. had also a large percentage of employees -84 per cent.who said they were interested in, and satisfied with, their jobs. H. W. had only 60 per cent. who were satisfied.

So far we have not investigated any shop assistants, so we do not know to what extent, if at all, their relatively high sickness rates are due to the presence of psychoneurotics or to the nature of the work. It is to be noted that although the variation within these few firms is great, both as to quantity and quality of the illness, yet all have good material conditions.

There are many problems in connexion with this subject, some of which are in the process of investigation:

1. What part is played in the mind of the doctor as well as of the patient by the knowledge that there is practical security of tenure? There seems to be a tendency in such a case for a lengthier convalescence than where the position is risked, and that is not always beneficial.

2. What conditions affect the so-called " nervous disorders"? What occupations are most suitable for a " nervous" person, or will he break down in any occupation whatsoever?

3. In firms where there is a yearly increase in sickness, why should that increase be in disorders of a psychoneurotic type and not in those of an organic' nature?

4. In determining the incidence of disease, what part is played by the knowledge that "compensaticn" may be obtained? Where this factor has resulted in an increased rate, what type of person has been affected? What is the effect of allowing full payment for a fixed number of days?

5. Does the size of the firm make any difference? In a small firm a worker often feels more important, and knows that his work falls on someone else in the case of absence; he therefore may hesitate to stop away for trivial reasons.

6. Do people who do not stay away for trivial illnesses actually develop more serious illness than those who do?

REFERENCES.

${ }^{1}$ Industrial Sickness Statistics. Fifth Annual Report, Industrial Fatigue Research Board, 1925. Cramp. Industrial Fatigue Research Board, Report No. 43 .

\section{FULMINATING DYSENTERY IN A CHILD, CAUSED BY B. DYSENTERIAE SONNE.}

W. HOWEL EVANS, M.B., Ch.B., B.Sc.,

LECTURER IN PATHOLOGY, UNIVERSITY OF LIVERPOOL; PATHOLOGIST, ROYAL LIVERPOOL CHILDREN'S HOSPITAL, LIVERPOOL.

Since Sonne (1915) first isolated and described the organism now generally associated with his name as'a frequent cause of dysentery in Copenhagen, it has been very widely recognized in other countries. Thus its occurrence has been reported by d'Herelle, France (1916); Ohnell, 'Sweden (1917); Thjötta, Norway (1919); Mita, Japan. (1921); Patterson and Williams, Australia (1922); Smith, Scotland (1924 and 1926); Channon, England (1926); and Nabarro, England (1927).

In several of the reports it is specifically stated that the disease commonly produced by the bacillus is of mild character. Thjötta states that the organism would be more frequently found but for the fact that the only symptoms are those of a mild diarrhoea which does not require medical attention. Fraser, Kinloch, and Smith (1926), in reporting 33 such patients in Aberdeen, none of whom died, state that while in exceptional cases the symptoms are of urgent description, in the "vast majority" of cases the disease is relatively mild compared with Flexner dysentery. The present case is therefore exceptional in regard to the severity of the symptoms and the rapidity with which death was brought about.

The patient, E. B., aged 10 , was a strong and apparently robust schoolboy. He went to school as usual on the morning of September 8th, 1926, and at $10.30 \mathrm{a.m}$. vomited. He was sent home, and at 2 p.m. severe and frequent diarrhoea began, persisting until the evening, when the child appeared so ill that at 10 p.m. he was taken to the Royal Liverpool Children's Hospital. Death occurred at 3 a.m., September 9 th-that is, sixteen and a half hours after the onset of the first symptoms.

On admission to the hospital the child was unconscious and dehydrated. Temperature $105^{\circ} \mathrm{F}$., pulse 150 . No stools were passed while in the hospital.

Necropsy, September 9th, 2 p.m. (eleven hours after death). The body was that of a well-grown boy of 10, but showing marked dehydration. The large intestine and lower part of the ileum were intensely congested, and contained reddish fluid and mucus. The mesenteric glands in the ileo-caecal angle were soft and red, and the Peyer's patches in the terminal part of the ileum were slightly swollen and red. The proximal part of the small bowel was practically unaffected. There was no ulceration in any part of the intestine. The thymus and other lymphoid tissues were normal for the age of the child. 
Microscopically the intestine showed nothing beyond intense congestion and catarrh. Death was therefore due to an intense intoxication, there being no time for structural changes to be produced.

Cultures from the contents of the large intestine and from the ileo-caecal lymphatic glands yielded abundant and almost pure growths of the Sonne bacillus, but cultures from the contents of the ileum, spleen, and heart blood were negative.

The bacillus had the following characters. On the MacConkey plate it formed rather large, opaque, rounded colonies, which at first remained colourless. Subcultures into the fluid sugar media gave the results tabulated below :

$\begin{array}{lllllll}\text { Lactose } & \ldots & \ldots & \ldots & \ldots & \ldots & \text { Acid on 6th day. } \\ \text { Glucose } & \ldots & \ldots & \ldots & \ldots & \ldots & \text { Acid in } 24 \text { hours. } \\ \text { Mannite } & \ldots & \ldots & \ldots & \ldots & \ldots & \text { Acid in } 24 \text { hours. } \\ \text { Maltose } & \ldots & \ldots & \ldots & \ldots & \ldots & \text { Acid in } 72 \text { hours. } \\ \text { Saccharose } & & \ldots & \ldots & \ldots & \ldots & \text { Unchanged. } \\ \text { Gelatin } & \ldots & \ldots & \ldots & \ldots & \ldots & \text { No liquefaction. } \\ \text { Indol } & \ldots & \ldots & \ldots & \ldots & \ldots & \text { Negative. } \\ \text { Motility } & \ldots & \ldots & \ldots & \ldots & \ldots & \text { Negative. }\end{array}$

It was not agglutinated by Shiga, Flexner, typhoid, and paratyphoid antiserums, but it was strongly agglutinated in the first subculture by a Sonne antiserum obtained by the kindness of Professor Cruickshank of Aberdeen. Later, at the request of Dr. A. D. Gardner of the Standards Laboratory, Oxford, the strain was sent to him and its serological identity independently confirmed

There are two difficulties in connexion with this organism which probably account for its infrequent recognition in the past. When first isolated the majority of the strains ferment lactose very late-six to ten days-and are therefore regarded as non-lactose fermenters. As they are not agglutinated by the usual standard antiserums, as detailed above, they have been frequently regarded as " ingglutinable Flexner" strains. On the other hand, as pointed out by Thjötta, the strain may ferment lactose in two ar three days, and may therefore not be distinguished from colon bacilli growing on the same plate. Final proof can only be obtained by serological tests, and fortunately the group specificity is very high.

Inquiries entirely failed to elicit the source of the infection. No further case occurred in the child's family or apparently in the school.

\section{References.}

Channon, H. A. (1926): Journ. Path, and Bact., xxix, 496.

d'Herelle, H. (1916): Ann. de l'Inst. Pasteur, xxx, 145.

Fraser, A. M., Kinloch, J. P., and Smith, J. (1926): Journ. Hygiene, xxv,

Mita, K. (1921) : Journ. Infect. Dis., xxix, 580.

Nabarro, D. (1927): Journ. Path. and Bact., xxx, 176.

Ohnell, H. (1918): Quoted by Thjötta, infra.

Patterson, S. W., and Williams, F.E. (1922): Journ. Path. and Bact., $\mathbf{x x v}, 393$.

Smith, J. (1924-25): Journ. Hygiene, xxiii, 94.

Sonne; C. (1915) : Centrall. of Balkt, lxxv; 408:

Thjötta, Th. (1919) : Journ. Bact., iv, 355.

\section{LIMITATIONS OF THE AGGLUTINATION REACTION IN THE DIAGNOSIS OF BACILLARY DYSENTERY. \\ BY}

J. MENTON, L.R.C.P. AND S.I., COUNTY BACTERIOLOGICAL LABORATORY, LICHFIELD.

A RECENT outbreak involving 120 cases afforded an opportunity of further investigating the reliability of the usual routine agglutination tests in the diagnosis of bacillary dysentery. Standardized cultures and the technique recommended by Professor Dreyer were employed for estimating the agglutinins; in the absorption tests the procedures detailed in the Medical Research Council Special Report Series No. 51 were followed, and each absorption experiment was controlled by comparison with known dysentery strains. Blood samples were examined from 47 affected individuals, of which 19 were positive to the Flexner group and 28 were negative.

Ten cases, positive later, were negative at the first examination. The duration of disease at the first and second tests in these ten cases was as illustrated in the following table.
Table showing Duration of Discase at First and Sccond Tests in Ten Cases of Bacillary Dysentery.

\begin{tabular}{|c|c|c|c|c|c|c|c|c|}
\hline \multicolumn{4}{|c|}{ At Time of Negative Reaction. } & \multicolumn{5}{|c|}{ At Time of Positive Reaction. } \\
\hline $\begin{array}{c}\text { Duration o } \\
\text { Disease. }\end{array}$ & & & $\begin{array}{l}\text { No. of } \\
\text { Cases. }\end{array}$ & Dura & $\begin{array}{l}\text { tion } \\
\text { ease. }\end{array}$ & & & $\begin{array}{l}\text { No. of } \\
\text { Cases. }\end{array}$ \\
\hline $\begin{array}{r}3 \text { days } \\
8 \quad, \\
11 \quad, \\
12 \quad, \\
15 \quad, \\
16 \quad, \\
17 \quad,\end{array}$ & $\begin{array}{c}\ldots \\
\ldots \\
\ldots \\
\ldots \\
\ldots \\
\cdots \\
\cdots\end{array}$ & $\begin{array}{c}\ldots \\
\ldots \\
\ldots \\
\ldots \\
\ldots \\
\ldots \\
\ldots\end{array}$ & $\begin{array}{ll}\ldots & 1 \\
\ldots & 3 \\
\ldots & 1 \\
\ldots & 1 \\
\ldots & 2 \\
\ldots & 1 \\
\ldots & 1\end{array}$ & $\begin{array}{r}5 \\
16 \\
30 \\
32 \\
33 \\
34 \\
38 \\
39\end{array}$ & $\begin{array}{c}\text { days } \\
,, \\
, \\
, \\
,, \\
,,\end{array}$ & $\begin{array}{l}\ldots \\
\ldots \\
\ldots \\
\ldots \\
\ldots \\
\ldots \\
\ldots \\
\ldots\end{array}$ & $\begin{array}{l}\ldots \\
\ldots \\
\ldots \\
\ldots \\
\ldots \\
\ldots \\
\ldots \\
\ldots\end{array}$ & $\begin{array}{ll}\ldots & 1 \\
\ldots & 2 \\
\ldots & 1 \\
\ldots & 1 \\
\ldots & 1 \\
\ldots & 1 \\
\ldots & 2 \\
\ldots & 1\end{array}$ \\
\hline
\end{tabular}

Predominant agglutinins for Flexner's bacillus Type V were present in the ten specimens, and ranged from 4 to 114 units per cubic centimetre of serum; five of them which showed 23 units or over were from patients who had been ill for thirty days or longer. One case of thirtyeight days' duration showed only 4 units, and the remainder reacted in the neighbourhood of 11 units. Agglutinins were also present for Type $W$, but to a less degree in 7 . of these cases. Two of the serums showing 114 units to Type $V$ contained 65 units to Type W. Of the three samples negative to Type $W$ one showed 4 units and two 11 to Type $V$. Agglutinins to $T_{y p e} \mathbf{Y}$ were present in all ten, and ranged from 4.4 to 8.8 units. Completely negative results were obtained with Sonne cultures and with Types $\mathbf{X}$ and $\mathbf{Z}$. Absorption experiments pointed to a Type $\mathbf{V}$ infection, the reactions to the other types being attributed to the phenomenon of coagglutination. This diagnosis was supported by the isolation of Flexner's bacillus Type $\mathbf{V}$ from some of the cases in the same outbreak.

As the investigation proceeded it was noticed that all the specimens did not react in a similar manner to the first batch, and although a Type $\mathbf{V}$ culture was still agglutinated in the highest dilution, on translating the results into agglutinin units it was found that some of the specimens contained more agglutinins to Type $\mathrm{W}$ than to Type $\mathrm{V}$; the suspension factor for the $V$ culture was 11 , while that for the $W$ culture was only $\mathbf{1 . 9}$.

A Flexner bacillus was now isolated from the faeces of one of the cases, which proved on absorption to be Type $W$ and not Type $V$. This point was verified by immunization tests. It was agglutinated by several of the positive serums, whether from the Type $V$ or Type $W$ cases; but without marked predilection, except that the serum of the patient from which it was recovered agglutinated it up to 1 in 5,000. This serum presented a peculiar anomaly-showing more agglutinin units to Type $V$ than to Type $W$ in the routine test, but absoiption tests conducted on it with known $\mathbf{V}$ and $\mathbf{W}$ cultures were inconclusive. There was insufficient serum to repeat the investigation, and, owing to circumstances orer which there was no control; a month elapsed before another specimen could be obtained; by that time the agglutinins had greatly diminished, and those to Type W were principal and predominant. This isolated bacillus only agglutinated the three stock standard antiserums $\mathbf{V}, \mathbf{W}$, and $Y$ up to a dilution of 1 in 125, but all the agglutinins were removed from the $W$ antiserum by absorption with it, while the $\mathbf{V}$ and $\mathbf{Y}$ antiserums were but slightly affected.

An important fallacy in the routine test was discernible in some of the early and late cases in which the agglutinins were not present in high amount. For instance, an estahlished Type $\mathrm{W}$ infection reacted in late convalescence to Type $V \dot{1}$ in 25 and 1 in 50 , and was negative to Type $W$ in these dilutions, but reacted to it in lower dilutions. This, effect was due to the great difference in the agglutinability of the respective cultures. The discrepancies which may arise when using dilutions of serum below 1 in 25 are recognized, but the example is tentatively put forward to illustrate what may happen when working with cultures possessing widely different suspension factors.

Taking the total 19 positives, 10 worked out as a Type $V$ infection, and 2 were established as due to Type $W$. There were probably other cases of Type W among the 7 remaining positives and the 28 negatives, but owing to difficulties in procuring repeat specimens, and the fact that the Type W infection was not diagnosed until late in the 